\title{
EXPERIMENTAL TOXOPLASMOSIS IMPACT ON MALE GENERATIVE SYSTEM: HISTOPATHOLOGY AND HORMONAL ASSAYS
}

\section{BY}

\author{
DOAA R. SAYED ${ }^{1}$, NABIL S. GABR ${ }^{2}$, RAAFAT M. SHAAPAN ${ }^{3}$, \\ RABIE M. MOHAMED ${ }^{2}$ and MARWA A. GHIETH ${ }^{1 *}$
}

Department of Medical Parasitology ${ }^{1}$, Faculty of Medicine, Beni-Suef University, Department of Parasitology22, Faculty of Medicine, El Minia University, and Department of Zoonotic Diseases ${ }^{3}$, National Research Center, Giza, Egypt.

( ${ }^{\star}$ Correspondence: marwaghieth@yahoo.com)

\begin{abstract}
The protozoan $T$. gondii infects human and animals. The parasite can alter the generative system affecting fertility. This work studied the impact of toxoplasmosis on male generative system in rats. 49 laboratory breed Wistar rats were divided into group I containing 35 rats and group II 14 control. About $0.5 \mathrm{ml}$ of the withdrawn peritoneal exudates contained $2 \times 10^{6}$ tachyzoites RH strain type I was inoculated intraperitoneally into each rat of GI. On days $10,20,30,40,50,60 \& 70$ post-inoculation (PI). Seven rats were anesthetized 5 from GI and 2 from GII each time. Both testes were removed, weighed, body and testis weight ratio (BTR) was calculated. Left testis was kept for histopathology and right testis was processed for tissue homogenate preparation and estimation of intratesticular testosterone (ITT) and lactate dehydrogenase (ITLDH). For BTR, slightly or no difference was detected. Mean level of ITT was significantly decreased in GI throughout the 70 days, ITLDH was higher in GI especially on days 40,50, $60 \& 70(\mathrm{P}<0.05)$. Detection of tachyzoites within seminiferous tubules on day $10 \mathrm{PI}$, with aggregation on day 30. Engorged blood vessels, degenerated, oedematous vessels, empty seminal vesicle with increasing number of tachyzoite and bradyzoite in cyst were detected. In GII, germinal cells were available with non detectable pathology. Toxoplasmosis altered hormonal ITT and ITLDH which was linked to testicular damage in male rats.
\end{abstract}

Key words: Toxoplasmosis, Rats, Experimental, Hormonal, Histopathology

\section{Introduction}

Toxoplasma gondii infects human and all animals as well as birds (Długońska, 2008). The sequels caused by toxoplasmosis varied from asymptomatic to congenital affection passing with abortion, still birth, neonatal death and fertility alteration (Dubey, 2010).

Besides, Toxoplasma adverse outcomes on female genital tract (Jones et al, 2003), the parasite has the ability to affect male generative system (Garcia et al, 1996).

Chronic infection of $T$. gondii in animals alter the reproductive parameters in males (Arantes et al, 2009; Kaňková et al, 2011). Terpsidis et al. (2009) reported Toxoplasma isolation from semen in male rats and infection was a fertility predictive factor.

Experimentaly, secondary hypogonadism was reported among the mice infected with toxoplasmosis, by virtue of the hypothalamic dysfunction (Antonios et al, 2000). Hypogonads in man in behalf of toxoplasmosis was mentioned, but without satisfactory determinations in the human beings (Oktenli et al, 2004).

Sufficient data were needed to clarify the effect of $T$. gondii on male reproductive system.

This study aimed to analyse the impact of toxoplasmosis on male reproductive system in clean laboratory bred Wistar rats by using the histopathology and hormonal assay.

\section{Material and Methods}

Ethical considerations: All experiment procedures were carried out in accordance to the guiding principles of the European Council Directive (86/609/EU) in what concern utilizing and breeding of laboratory animals. The experiment protocol was approved by The National Research Center, Egypt.

Animals and infection procedures: A total number of 49 laboratory breeding Wistar rats were obtained and breed at the animal house laboratory in The National Research Center, Egypt. Rats were housed in optimal 
conditions of temperature and humidity, kept in clean cages and fed on pelleted food and water. They were about 30days old, with body weight varies from 200 to $250 \mathrm{gm}$. The experiment was started at day 40 of age of rat, 10 days was taken for adjustment of experiment conditions. All rats were confirmed to be toxoplasmosis-free using modifyed agglutinatin Test (MAT) after Dubey and Desmonts (1987) at a dilution of 1:25.

Male rats were divided into GI included 35 rats (cases) that later were infected by $T$. gondii and GII included 14 non infected rats (control).

T. gondii strain: RH-Virulent type I $T$. gondii local strain was used for experimental infection obtained by Shaapan et al. (2008), using bioassay trails on the suspected infected sheep tissues and in order to isolate the $T$. gondii infective stages, cats and mice were used. The recovered tachyzoites of $T$. gondii local strain was maintained in the Laboratory of Zoonotic Diseases Department, National Research Center, Egypt.

Infection procedures: At the start of the procedure the rat's age was 40 days. GI were infected (Dube, 2010) by peritoneal inoculation of about $0.5 \mathrm{ml}$ of taspirated peritoneal exudates containing $\left(2 \times 10^{6}\right)$ tachyzoites (RH strain type 1). Then, GI rats were confirmed to be infected with $T$. gondii on $6^{\text {th }}$ day post infection according to Baumgarth et al. (2000) by serological examination using Latex Agglutination Test (LAT), detected IgM antibodies. Rats were left for 4 days and then on days $10^{\text {th }}, 20^{\text {th }}, 30^{\text {th }}, 40^{\text {th }}, 50^{\text {th }}, 60^{\text {th }} \&$ $70^{\text {th }}$ days post-ino-culation (PI) 5 rats from GI \& 2 rats from GII were anesthetized.

Calculation of body and testis weight ratio (BTR): The body weight of each anesthetized rat was measured then both testes were immediately removed and weighed. The mean weight of both testes were recorded for each animal. Then ratio of body weight to testes weight (BTR) was estimated by measuring the mean weight of both testes in relation to the terminal body weight just before necrosis. The left testis was kept in sa- line at room temperature for testicular histopathological examination while the right testis was stored at $-20^{\circ} \mathrm{C}$ in saline solution for later preparation of tissue homogenate and hormonal assay.

Hormonal assays: The tissue homogenate from right testis was processed for measurement of ITT using ELISA assay (ElA Testosterone; Dia plus Inc., San Francisco, CA, USA) according the manufacturer's instructions. In addition to measuring ITLDH using spectrophotometer using commercal kits (EIA LDH Dia plus. Inc. CA, USA)

Histopathological examination: The left testis was taken to make 5- $\mu$ m paraffin sections after being suspended in the Bouin's fluid for two days. The sections were stained with hematoxylin and eosin $(\mathrm{H} \& \mathrm{E})$. The stained tissue sections were examined under the microscope at power magnification of X100 for identification of toxoplasma (Culling, 1974).

Statistical analysis: Data was analyzed by SPSS software version 16 . The quantitative data were conferred as mean \pm standard deviation. Comparison of quantitative variants between two groups was assessed by student t-test. Differences with $P$ values less than 0.05 were considered significant.

\section{Results}

All the rats in GI inoculated intraperitoneal proved to be infected as shown by the LAT. But, GII rats showed negative reaction.

Impact of toxoplasmosis on BTR: There was slightly or no differences between GI and GII on the BTR $(\mathrm{P}>0.05)$.

Impact of toxoplasmosis on ITT: The mean level of tissue testosterone was lower in GI throughout the seventy days. Diminished ITT mean level in GI was significantly during $10^{\text {th }}, 60^{\text {th }}, 70^{\text {th }}$ days PI $(\mathrm{P}<0.05)$. The lowest mean level was on $70^{\text {th }}$ day PI.

Impact of toxoplasmosis on ITLDH: The mean level of tissue ITLDH was higher in GI compared to GII throughout the 70 days especially on days $40^{\text {th }}, 50^{\text {th }}, 60^{\text {th }}$ and $70^{\text {th }}(\mathrm{P}$ $<0.05)$.

Histopathology results: Among GI, abnor- 
malities were recorded by tachyzoites within the seminiferous tubules on the $10^{\text {th }}$ day PI, that increased from the $30^{\text {th }}$ till $60^{\text {th }}$ day PI with aggregation (Fig. 1). The engorged blood vessels appeared on the $20^{\text {th }}$ day PI reached a peak on the $40^{\text {th }}$ day PI, degenerated and oedematous vessels within the seminiferous tubules appeared on $40^{\text {th }}$ day PI (Fig. 2). On the $50^{\text {th }}$ day, some of the seminal vesicle appeared empty with increasing number of tachyzoite and bradyzoite in cyst

Table 1: Mean of body weight in GI and GII

\begin{tabular}{|l|c|c|c|c|c|}
\hline \multirow{2}{*}{ Test Day } & \multicolumn{2}{|c|}{ GI $(\mathrm{n}=35)$} & \multicolumn{2}{c|}{ GII $(\mathrm{n}=14)$} & \multirow{2}{*}{ P value } \\
\cline { 2 - 5 } & Mean & Std. Deviation & Mean & Std. Deviation & \\
\hline 10 days & 0.245 & 0.44 & 0.248 & --- & 0.137 \\
\hline 20 days & 0.243 & 0.13 & 0.245 & --- & 0.098 \\
\hline 30 days & 0.214 & 0.14 & 0.215 & --- & 0.147 \\
\hline 40 days & 0.160 & 0.40 & 0.164 & --- & 0.110 \\
\hline 50 days & 0.196 & 0.16 & 0.148 & --- & 0.089 \\
\hline 60 days & 0.135 & 0.20 & 0.137 & --- & 0.182 \\
\hline 70 days & 0.133 & 0.35 & 0.134 & --- & 0.073 \\
\hline
\end{tabular}

Table 2: Mean of ITT in GI and GII

\begin{tabular}{|c|c|c|c|c|c|}
\hline \multirow{2}{*}{$\begin{array}{l}\text { Testosterone } \\
\text { Test Day }\end{array}$} & \multicolumn{2}{|r|}{ GI } & \multicolumn{2}{|r|}{ GII } & \multirow[t]{2}{*}{$P$ value } \\
\hline & Mean & Std. Deviation & Mean & Std. Deviation & \\
\hline 10 days & 236.3 & 4.8 & 250 & --- & $0.019 *$ \\
\hline 20 days & 241.3 & 10.3 & 250 & --- & 0.321 \\
\hline 30 days & 240 & 14.1 & 260 & --- & 0.132 \\
\hline 40 days & 238.8 & 11.8 & 250 & --- & 0.273 \\
\hline 50 days & 238.8 & 8.5 & 255 & --- & 0.064 \\
\hline 60 days & 233.8 & 4.8 & 260 & --- & $0.002 *$ \\
\hline 70 days & 210 & 8.2 & 270 & --- & $0.001 *$ \\
\hline
\end{tabular}

Table 3: Mean of ITLDH in GI and GII

\begin{tabular}{|c|c|c|c|c|c|}
\hline \multirow{2}{*}{$\begin{array}{l}\text { LDH Test } \\
\text { Day }\end{array}$} & \multicolumn{2}{|r|}{ GI } & \multicolumn{2}{|r|}{ GII } & \multirow[t]{2}{*}{$P$ value } \\
\hline & Mean & Std. Deviation & Mean & Std. Deviation & \\
\hline 10 days & 101 & 31.2 & 40 & --- & 0.079 \\
\hline 20 days & 108.8 & 8.5 & 85 & --- & 0.055 \\
\hline 30 days & 176.3 & 46.4 & 90 & --- & 0.068 \\
\hline 40 days & 160 & 45.5 & 40 & --- & $0.024 *$ \\
\hline 50 days & 157.5 & 42.7 & 30 & --- & $0.016 *$ \\
\hline 60 days & 240 & 45.5 & 50 & --- & $0.005^{*}$ \\
\hline 70 days & 325 & 117.3 & 30 & --- & $0.029 *$ \\
\hline
\end{tabular}

\section{Discussion}

For years rats were used as an animal model for Toxoplasma infection (Dubey and Frenkel, 1998). In this experimental study, rats were used to encounter the impact of $T$. gondii on the male rat's reproductive system

Acute toxoplasmosis infection proved to be an agent for unproductiveness among experimentally tested male rats (Lu et al, 2005; Sun et al 2008; Terpsidis et al 2009; Abdoli et al, 2012). It induced harm to testicular on the $70^{\text {th }}$ day PI (Fig. 3). Aggregated tachyzoites was detec- ted within the blood vessel wall on the $70^{\text {th }}$ day PI (Fig. 4).

Regaring GII, the germinal cells within the seminiferous tubules were available on the $10^{\text {th }}$ day and the $30^{\text {th }}$ day with normal sperm and seminiferous tubules filled with seminal fluid.

Details were given in tables $(1,2 \& 3)$ and figures $(1,2,3 \& 4)$. 
(Barreto et al, 2008) were reported. Besides, Eslamirad et al. (2013) reported that chronic toxoplasmosis influenced human reproductive parameters. Santana et al. (2010) suggested possibility of venereal transmission of $T$. gondii among goats which should be further assessed.

In the present study, there was limited or no differences between GI and GII on the BTR (P > 0.05). In the same way, Abdoli et al. (2012) reported no significant difference on BTR between infected and control. Also, Dvorakova-Hortova et al. (2014) did not find significant differences between infected and control mice.

Testosterone hormone is chiefly created in testis, the present results revealed that, the mean level of ITT was lower among group I throughout the 70 days, with significant difference during 10, $60 \& 70$ days PI $(\mathrm{P}<$ $0.05)$, reaching minimum level on $70^{\text {th }}$ day PI. This result agreed with Rui et al. (2009) attributing to induction of spermatogenic apoptosis by diminished local testosterone range and subsequent testicular damage (Zhou et al, 2004). Also, Abdoli et al. (2012) reported a decrease of ITT. Flegr et al. (2005) and Hodková et al. (2007) could n't drive either the diminished in testosterone levels or no changes occur in toxopla-smosis and they attributed hormonal changes to be subjectively.

LDH is an indicator of cell stress during tissue damage, it was released during anaerobic glycolysis (Adiga and Jagetia, 1999). The present results showed that, the mean level of tissue LDH was higher in GI compared to GII throughout the 70 days especially on days 40, 50, $60 \& 70(\mathrm{P}<0.05)$. Suzuki et al. (1971) reported LDH declined during acute toxoplasmosis There is a link between levels of ITLDH and degree of tissue damage, some authors showed minimal changes in tissue LDH due to minimal or non-detected pathology in testes by toxoplasmosis (Abdoli et al, 2012).

The present histopathologic results detected tachyzoites within the seminiferous tubu- les on $10^{\text {th }}$ day PI and increased throughout the experiment to reach parasitic aggregation on $60^{\text {th }}$ day PI. The testicular architecture showed abnormalities in form of engorged blood vessels, degenerated and oedematous vessels within the seminiferous tubules, empty seminal vesicle and increased the number of tachyzoite and bradyzoite in cyst.

This result agreed with Arantes et al. (2009) who isolated $T$. gondii in seminal fluid, testicular and epididymal tissues from dogs Also, Koch et al. (2016) mentioned isolation of the parasite from dogs seminal fluid.In contrast, Terpsidis et al. (2009) did not detect abnormalities in histopathology of the testes of infected rates. Damage caused by toxoplasmosis pointed to Th1 dominated effect and the released cytokines especially nitric oxide, reactive oxygen species (Miller et al, 2009). However, they countered protective effect that caused cell damage. Oktenli et al. (2004) reported that acute $T$, gondii infection might cause temporary hypo gonadotrophic gonadal insufficiency regardless the course of toxoplasmsis. Another explanation was added by Dvorakova-Hortova et al. (2014) that toxoplasmisi has the ability to adjust epi genome of host testes. Through linking between unusual DNA methylation \& comprom ised spermatogenesis. But, mechanism was quite obscure. It was vital to determine whether toxoplasmosis affect male reproductive system that would reflect on understanding its pathogensis and infection outcome.

\section{Conclusion}

Undoubtedly, since the discover of $T$. gondii over two hundred years ago was immediately recognized as a pathogen disease responsible for congenital complications.

The outcome data proved that Toxoplasma could affect male genital tract in rats, it can significantly alter the tissue hormones ITT \& ITLDH which are allied with testicular damage in male rats. More studies are ongoing and will be published in due time elsewhere.

\section{Referencess}

Abdoli, A, Dalimi, A, Movahedin, M, 2012: Impaired reproductive function of male rats in- 
fected with Toxoplasma gondii. Andrologia, 44:679-687 10.1111/j.1439-0272.2011.01249

Adiga, SK, Jagetia, GC 1999: Effect of teniposide $(\mathrm{Vm}-26)$ on the cell survival, micronuclei induction and lactate dehydrogenase activity on V79 cells. Toxicology 138:29-41.

Antonios, S, Ismail H, Essa, T, 2000: Hypothalamic origin of reproductive failure in chronic experi-mental toxoplasmosis. J. Egypt. Soc. Para sitol. 130, 2:593-9

Arantes, TP, Lopes, WDZ, Ferreira, RM, Pieroni, JS, Pinto, VM, et al, 2009: Toxoplasma gondii Evidence for the transmission by semen in dogs. Exp. Parasitol. 123, 2:190-4.

Barreto, F, Hering, F, Dall'oglio, MF, Martini, Filho, D, Campagnari, JC, et al, 2008: Testicular toxoplasmosis: a rare case of testicular mass. Actas. Urol. Esp. 32:666-8.

Baumgarth, N, Herman, OC, Jager, GC, Brown,LE, Herzenberg, LA, et al, 2000: B-1 and B-2 cell-derived immunoglobulin $\mathrm{M}$ antibodies are nonredundant components of the protective response to influenza virus infection. J. Exp. Med. 192:271-80.

Culling, CFA, 1974: Hand book of histopathological and histochemical techniques 3rd ed. Printed in Great Britain by Redwood Burn Ltd., Trowbridge and Escher.

Długońska, H, 2008: Toxoplasma gondii, known and unknown parasite. Wiad. Parazytol. 54, 3:199-204

Dubey, JP, 2010: Toxoplasmosis of Animals and Humans, $2^{\text {nd }}$ edn. CRC Press, Boca Raton, FL, USA.

Dubey, JP, Desmonts, G, 1987: Serological responses of equines fed T. gondii oocysts. Equine Vet. J. 19:337-9.

Dubey, JP, Frenkel, JK, 1998: Toxoplasmosis in rats: A review with considerations of their value as an animal model and their possible role in epidemiology. Vet. Parasitol. 77, 1-32.

Dvorakova-Hortova, K, Sidlova, A, Ded, L, Hladovcova, D, Vieweg, M, et al, 2014: Toxoplasma gondii Decreases the Reproductive Fitness in Mice. PLoS ONE 9(6): e96770. https:// doi.org/10.1371/ journal.pone.0096770

Eslamrad, Z, Hajihossein, R, Ghorbanzadeh, B, Alimhammadi, M, Mosayeb, M, Didehdar, M, 2013: Effects of Toxoplasma gondii infection in level of serum testosterone in males with chronic toxoplasmosis. Iran. J. Parasitol. 8, 4: 622-6.

Flegr, J, Hruskova, M, Hodny, Z, Novotna,
M, Hanusova, J, 2005: Body height, body mass index, waist-hip ratio, fluctuating asymmetry and second to fourth digit ratio in subjects with latent toxoplasmosis. Parasitology 130, 6:621-8. Garcia, MF, Regadera, J, Mayer, R, Sanchez, S, Nistal, M, 1996: Protozoan infections in the male genital tract. J. Urol. 156:340-9.

Hodková, H, Kolbeková, P, Skallová, A, Lindová, J, Flegr, J. 2007: Higher perceived dominance in Toxoplasma infected men-A new evidence for role of increased level of testosterone in toxoplasmosis-associated changes in human behavior. Neuroendocrinol. Lett. 28, 2:110-4. Jones, J, Lopez, A, Wils, NM, 2003: Congenital toxoplasmosis. Am. Fam. Physici. 67:2131-8. Kaňková, Š, Kodym, P, Flegr, J, 2011: Direct evidence of Toxoplasma-induced changes in serum testosterone in mice. Exp. Parasitol. 128, 3: 181-3

Koch, MO, Weiss, RR, Cruz, AA, Soccol, VT, Gonçalves, KA, et al, 2016: Detection and isolation of Toxoplasma gondii from fresh semen of naturally infected dogs in Southern Brazil. Reprod. Domest. Anim. 51, 4:550-4.

Lu, M, Yang, LD., Chen, CY., Wu, XZ, Gong, F, 2005: Infertility experiment on male mice infected with Toxoplasma (In Chinese with English abstract). Chin. J. Zoono. 21, 592-4.

Miller, CM, Boulter, NR, Ikin, RJ, Smith, NC 2009: The immunobiology of the innate response to Toxoplasma gondii. Int. J. Parasitol. 39: 23-39.

Oktenli, C, Doganci L, Ozgurtas, T, Engin Araz, T, Tanyuksel, M, et al, 2004: Transient hypogonadotrophic hypogonadism in males with acute toxoplasmosis: Suppressive effect of interleukin- $1 \beta$ on the secretion of GnRH. Hum. Reprod. 19, 4:859-66

Patton, PE, Battaglia, DE 2005: Office Andrology. Humana. Press. Inc. Totowa, NJ, USA. Qi, R, Su, XP, Gao, XL, Liang, XL, 2005: Toxoplasma infection in males with sterility in Shenyang, China (In Chinese with English abstract). Zhonghua Nan Ke Xue 11:503-4.

Rui, Y, Qiang, X, Mingzhe, J, 2009: Effect of abnormal gonadal hormone secretion caused by Toxoplasma gondii in male fertility descent (In Chinese with English abstract). Mod. Prev. Med. 36:4130-2.

Santana, LF, da Costa, AJ, Pieroni, J, Lopes, WD, Santos, RS, et al, 2010: Detection of Toxoplasma gondii in the reproductive system of male goats. Rev. Bras. Parasitol Vet. 19, 3:179-82. 
Shaapan, RM, El-Nawawi, FA, Tawfik, MA A, 2008: Sensitivity and specificity of various serological tests for the detection of Toxoplasma gondii infection in naturally infected sheep. Vet. Parasitol. 153:359-62.

Shen, L, 2001: Pathology and pathogenetic study of the Toxoplasma gondii acute infection mice testis (In Chinese with English abstract). Chin. J. Zoono.17:75-7.

Sun, LH, Fan, F, Wang, JJ, Gong, J, 2008: Acute Toxoplasma gondii infection affects the repro-ductive function of male mice. Zhonghua. Nan. Ke. Xue. 14, 55-7.

Suzuki, N, Piekarski, G, Janssen, P, Viswanathan, R, 1971: Biochemical observations of blood of rat Infected with Toxoplasma gondii. Res. Bull. Obihiro. Univ. 7:15-25.
Terpsidis, KI, Papazahariadou, MG, Taitzoglou, IA, Papaioannou, NG, Georgiadis, MP, et al, 2009: Toxoplasma gondii: Reproductive parameters in experimentally infected male rats. Exp Parasitol. 121, 3:238-41.

Zhou, YH, Lu, YJ, Wang, RB, Song, LM, Shi, F, et al, 2002: Survey of infection of Toxoplasma gondii in infertile couples in Suzhou countryside (In Chinese with English abstract). Zhonghua Nan Ke Xue 8:350-2

Zhou, YH, Shi, H, Hu, Y, Lu, Y, Zhong, X, et $a l, 2004:$ Study on the damages on the reproductive system of male rats induced by Toxoplasma gondii infection and its regulatory mechanism (In Chinese with English abstract). Chin. J. Zoonos. 20:989-93.

\section{Explanation of figures}

Fig. 1: Tachyzoites within seminiferous tubules with aggregations (x100, H\&E stain).

Fig. 2: Engorged blood vessels, degenerated and oedematous vessels within seminiferous tubules (x40, H\&E stain)

Fig. 3: Empty seminal vesicle appeared empty with Increasing number of tachyzoite and bradyzoite in cyst (x100, H\&E stain)..

Fig. 4: Aggregated tachyzoites detection within the blood vessel wall (x100, H\&E stain) 

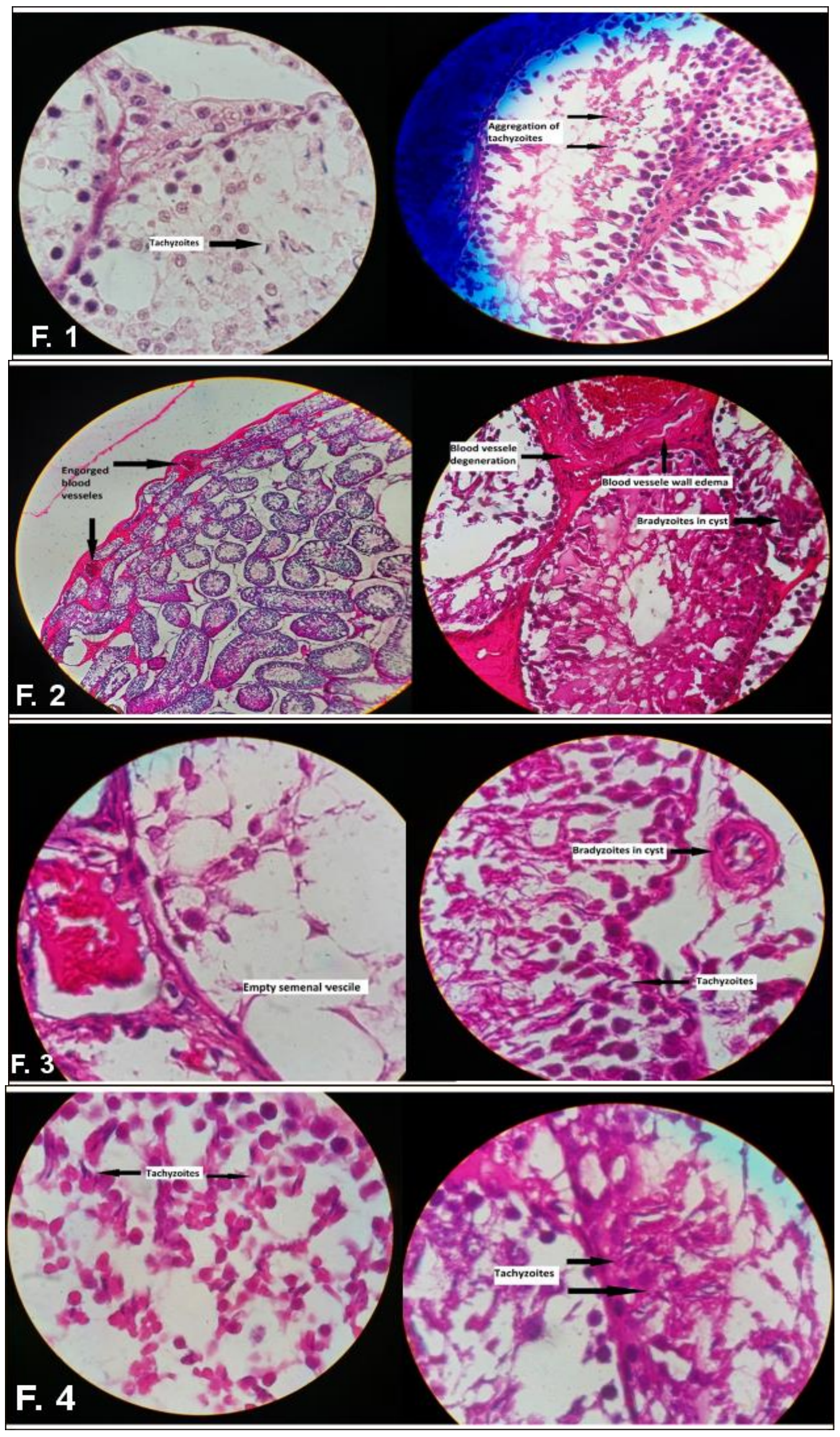